\title{
Spatiotemporal Analysis of Surface Water Quality in Dong Thap Province, Vietnam Using Water Quality Index and Statistical Approaches
}

\author{
Nguyen Thanh Giao* ${ }^{\mathbb{D}}$, Phan Kim Anh and Huynh Thi Hong Nhien \\ College of Environment and Natural Resources, Can Tho University, Can Tho 900000, Vietnam; \\ hanhmt26@gmail.com (P.K.A.); giaodanida@gmail.com (H.T.H.N.) \\ * Correspondence: ntgiao@ctu.edu.vn
}

Citation: Thanh Giao, N.; Kim Anh,

P.; Thi Hong Nhien, $\mathrm{H}$.

Spatiotemporal Analysis of Surface Water Quality in Dong Thap Province, Vietnam Using Water Quality Index and Statistical Approaches. Water 2021, 13, 336. https://doi.org/ $10.3390 /$ w13030336

\section{Academic Editor:}

Bommanna Krishnappan

Received: 26 December 2020

Accepted: 26 January 2021

Published: 29 January 202

Publisher's Note: MDPI stays neutral with regard to jurisdictional claims in published maps and institutional affiliations.

Copyright: () 2021 by the authors. Licensee MDPI, Basel, Switzerland. This article is an open access article distributed under the terms and conditions of the Creative Commons Attribution (CC BY) license (https:// creativecommons.org/licenses/by/ $4.0 /)$

\begin{abstract}
The study was conducted to spatiotemporally analyze the quality, location and critical water variables influencing water quality using water monitoring data from the Department of Environment and Natural Resources, Dong Thap province in 2019. The water quality parameters including turbidity, $\mathrm{pH}$, temperature, dissolved oxygen (DO), total suspended solids (TSS), biological oxygen demand (BOD), chemical oxygen demand (COD), nitrite $\left({\mathrm{N}-\mathrm{NO}_{2}}^{-}\right)$, nitrate $\left(\mathrm{N}^{-\mathrm{NO}_{3}}{ }^{-}\right)$, ammonium $\left(\mathrm{N}-N H_{4}{ }^{+}\right)$, total nitrogen (TN), orthophosphate $\left(\mathrm{P}^{-} \mathrm{PO}_{4}{ }^{3-}\right)$, chloride $\left(\mathrm{Cl}^{-}\right)$, oil and grease, sulfate $\left(\mathrm{SO}_{4}{ }^{2-}\right)$, coliforms, and Escherichia coli (E. coli) were collected at 58 locations with the frequency of four times per year (February, May, August, and November). These parameters were compared with national technical regulation on surface water quality-QCVN 08-MT: 2015/BTNMT. Water quality index (WQI) was calculated and spatially presented by geographical information system (GIS) tool. Pearson correlation analysis, cluster analysis (CA), and principal component analysis (PCA) were used to evaluate the correlation among water quality parameters, group and reduce the sampling sites, and identify key parameters and potential water pollution sources. The results showed that TSS, BOD, COD, N-NH ${ }_{4}^{+},{\mathrm{P}-\mathrm{PO}_{4}}^{3-}$, coliforms, and $E$. coli were the significant concerns impairing the water quality. Water quality was assessed from poor to medium levels by WQI analysis. CA suggested that the current monitoring locations could be reduced from 58 sites to 43 sites which can be saved the total monitoring budget up to $25.85 \%$. PCA showed that temperature, $\mathrm{pH}, \mathrm{TSS}, \mathrm{DO}$, BOD, COD, N-NH ${ }_{4}{ }^{+}, \mathrm{N}^{-\mathrm{NO}_{2}}{ }^{-}, \mathrm{TN}, \mathrm{P}^{-} \mathrm{PO}_{4}{ }^{3-}$, coliforms, and E. coli were the key water parameters influencing water quality in Dong Thap province's canals and rivers; thus, these parameters should be monitored annually. The water pollution sources were possibly hydrological conditions, water runoff, riverbank erosion, domestic and urban activities, and industrial and agricultural discharges. Significantly, the municipal and agricultural wastes could be decisive factors to the change of surface water quality in the study area. Further studies need to focus on identifying sources of water pollution for implementing appropriate water management strategies.
\end{abstract}

Keywords: cluster analysis; dong thap; pearson correlation; principal component analysis; water quality

\section{Introduction}

Rivers play an essential role in creating habitats for many organisms and providing water for human activities. Meanwhile, the discharge of wastewater caused by industrial, urban, and other activities makes constant pollution sources, while surface water quality is seasonally changed. The flow discharge on the main Mekong River in Vietnam is divided into two distinct seasons: flood and dry seasons. The flood season is characterized by the enormous flow of 38,000-40,000 $\mathrm{m}^{3} / \mathrm{s}$, causing flooding of about 1.2-1.9 million ha with depths from 0.5 to $4.5 \mathrm{~m}$. In contrast, the dry season flow is $2000-2400 \mathrm{~m}^{3} / \mathrm{s}$, resulting in difficulty for water supply during agricultural production in Winter-Spring and SummerAutumn [1]. The Vietnamese Mekong Delta is at risk of facing a lack of surface water 
resources due to increasing water use in the upstream countries in the watershed and due to climate change. Therefore, the water supply capacity and water quality of the entire Mekong Delta present and the future are significant concerns.

The Mekong Delta is shrinking every year, especially in coastal provinces, because upstream hydropower dam construction has resulted in a significant reduction in sedimentation [2]. On the other hand, floodplain areas in the delta (Dong Thap Muoi and Tu Giac Long Xuyen) are less affected by tides and saline intrusion than the coastal regions [3]. They are still affected by upstream hydropower dam system activities, climate change, and socio-economic development activities. The operation of hydropower dams is expected to change river water levels by $26-70 \%$ in the dry season and $0.8-5.9 \%$ in the wet season [4] and could reduce the sedimentation quantity by $40 \%$ in the period of 2050-2060 [5]. Moreover, the change of surface water sources in the floodplain of the Mekong Delta also affects the socio-economic development of the neighboring areas [6]; in particular, the use of water for agricultural activities in inundation areas would directly affect the central and coastal regions of the Mekong Delta $[7,8]$.

Dong Thap is one of the low-lying provinces of the Mekong Delta where water quality can be greatly affected by the water quality degradation of the surrounding provinces. The province has a plentiful source of surface water, and freshwater is present all year round, which mainly provides for domestic use, e.g., bathing, cleaning of daily utensils, and cooking; agricultural cultivation (irrigation, washing alum, etc.), and aquaculture. However, in the deep lowland area in the center of Dong Thap province, water quality at the end of the dry season and early rainy season is affected by acid sulfate water due to the acidic soil properties in the study area. In addition to the two main rivers, Tien River and Hau River, the northern region is also influenced by So Ha and So Thuong rivers originating from Cambodia and flowing into the Tien and Hong Ngu rivers. The system of natural watercourses providing water supply and drainage for fields to Tien and Hau rivers consists of, for example, Ba Rang, Doc Vang Thuong, Doc Vang Ha, Cao Lanh, and Can Lo rivers in the north and Cai Tau Ha, Cai Tau Thuong, Sa Dec river, and Lap Vo-Lai Vung canal in the south. Due to the influence of natural features, rivers and canals in Dong Thap are strongly influenced by the flood regime in the rainy season, making it difficult to drain water during the flood period in the urban areas.

The surface water monitoring system provides useful information for socio-economic development activities and water resources management. However, the selection of the water quality indicators and the monitoring locations are mainly based on waste generation sources and the allocated funds [9]. Furthermore, the water quality monitoring in Vietnam has been done periodically every year at many different locations with a relatively large number of physicochemical indicators analyzed. Hence, there may be a number of sites where water quality is likely to be almost identical; therefore, this can lead to the monitoring task becoming costly and time-consuming. In Vietnam, the application of statistical approaches to develop water monitoring programs has not been common. Meanwhile, cluster analysis (CA), principal component analysis (PCA), and geographic information systems (GIS) have been used very popularly in the study of water quality monitoring systems [10-15]. The objective of this study was to identify the integrated water quality status, detect the interrelation among the variables, spatial variation in water, and critical water variables influencing water quality in Dong Thap province based on the water quality index and statistical approaches. The study results provide useful information to environmental managers in Dong Thap and the neighboring provinces to review the surface water monitoring system.

\section{Materials and Methods}

\subsection{The Study Area}

Dong Thap is one of the three provinces of Dong Thap Muoi, with a total area of $3384 \mathrm{~km}^{2}$ and a population of nearly 1.7 million people. The economy is mainly composed of food production, with rice output ranking the third in the country (3.07 million tons/year). 
Aquaculture has also been considered the second strength after rice cultivation, ranked first in the country in terms of export volume of pangasius. The structure of land use has about $2602 \mathrm{~km}^{2}$ of agricultural land, $111 \mathrm{~km}^{2}$ of forest land, $257 \mathrm{~km}^{2}$ of special-use land, and $146 \mathrm{~km}^{2}$ of residential land. The climate has tropical, hot and, humid, greatly influenced by seasonal monsoons, each year there are 2 main seasons: rainy and dry seasons. The annual average temperature of the province ranged from 26 to $27^{\circ} \mathrm{C}$, the average temperature variation was $3-4{ }^{\circ} \mathrm{C}$. The average annual rainfall was up to $1500 \mathrm{~mm}$, and the average relative humidity for many years was $82-83 \%$. Therefore, water quality can be affected by artificial sources, mainly agriculture, aquaculture and population. In addition, the sources of impacts from the natural environment recorded in Dong Thap at the beginning of the rainy season are alluvial water and acid sulfate water (water washing away acid sulfate materials on the soil surface), and at the end of the rainy season, they are alluvial water and water flowing from the upstream (for example, from Cambodia, Laos).

\subsection{Water Sampling and Analysis}

Seventeen water monitoring indicators at 58 sampling sites were collected by the Department of Natural Resources and Environment of Dong Thap province, Vietnam. Dong Thap's People Committee authorizes this department to monitor the environments including water, soil, sediment, and air quality in Dong Thap province. The characteristics of the waste sources, as well as the purposes of using water (domestic, agriculture, industry, aquaculture), form the basic monitoring objectives of the water quality monitoring program in Dong Thap province. The observed water quality parameters comprised temperature $\left({ }^{\circ} \mathrm{C}\right), \mathrm{pH}$, turbidity (NTU), dissolved oxygen (DO) $\left(\mathrm{mg} \mathrm{L}^{-1}\right)$, total suspended solids (TSS) $\left(\mathrm{mg} \mathrm{L}^{-1}\right), \mathrm{BOD}\left(\mathrm{mg} \mathrm{L}^{-1}\right), \mathrm{COD}\left(\mathrm{mg} \mathrm{L}^{-1}\right), \mathrm{N}-\mathrm{NO}_{2}{ }^{-}\left(\mathrm{mg} \mathrm{L}^{-1}\right), \mathrm{N}^{-N_{3}}{ }^{-}\left(\mathrm{mg} \mathrm{L}^{-1}\right), \mathrm{N}^{-\mathrm{NH}_{4}}{ }^{+}$ $\left(\mathrm{mg} \mathrm{L}^{-1}\right), \mathrm{TN}\left(\mathrm{mg} \mathrm{L}^{-1}\right), \mathrm{P}_{-} \mathrm{PO}_{4}{ }^{3-}\left(\mathrm{mg} \mathrm{L}^{-1}\right), \mathrm{Cl}^{-}\left(\mathrm{mg} \mathrm{L}^{-1}\right), \mathrm{SO}_{4}{ }^{2-}\left(\mathrm{mg} \mathrm{L}^{-1}\right)$, oil and grease $\left(\mathrm{mg} \mathrm{L}^{-1}\right)$, coliforms (MPN/100 mL) and E. coli (MPN/100 mL). The Mekong Delta region is located in the central tropical monsoon region of Asia; Climate was divided into the rainy season (May-October) and the dry season (November-April next year). The sample collection frequency was four times per year (February, May, August, and November) in 2019. Specifically, the sampling months were divided into dry season (February and November) and rainy season (May and August). The monitoring locations were mostly located along Tien River, Hau River, and infield canals in Dong Thap province which were shown in Figure 1. The description of the sampling sites are provided in the supplementary file (Table S1). Sampling, storage, and analysis methods were conducted according to the guidelines [16]. Turbidity, $\mathrm{pH}$, temperature, and $\mathrm{DO}$ were in situ determined by hand-held devices.

\subsection{Data Analysis}

The water quality parameters were compared with QCVN 08-MT: 2015/BTNMTNational technical regulation on surface water quality [9]. The water quality index (WQI) was calculated with the guidance of the Vietnam Environment Administration (2019) [17] and presented as a geographic map through the software QGIS version 3.14 (the Open Source Geospatial Foundation-OSGeo, Chicago, IL, USA). Then, the distribution of the colors was proposed based on the results of the prior WQI. Descriptive statistical, boxplots, one-way ANOVA (the post-hoc test using Ducan), and Pearson correlation analysis was performed using SPSS software (version 20.0, IBM Corp., Armonk, NY, USA). 


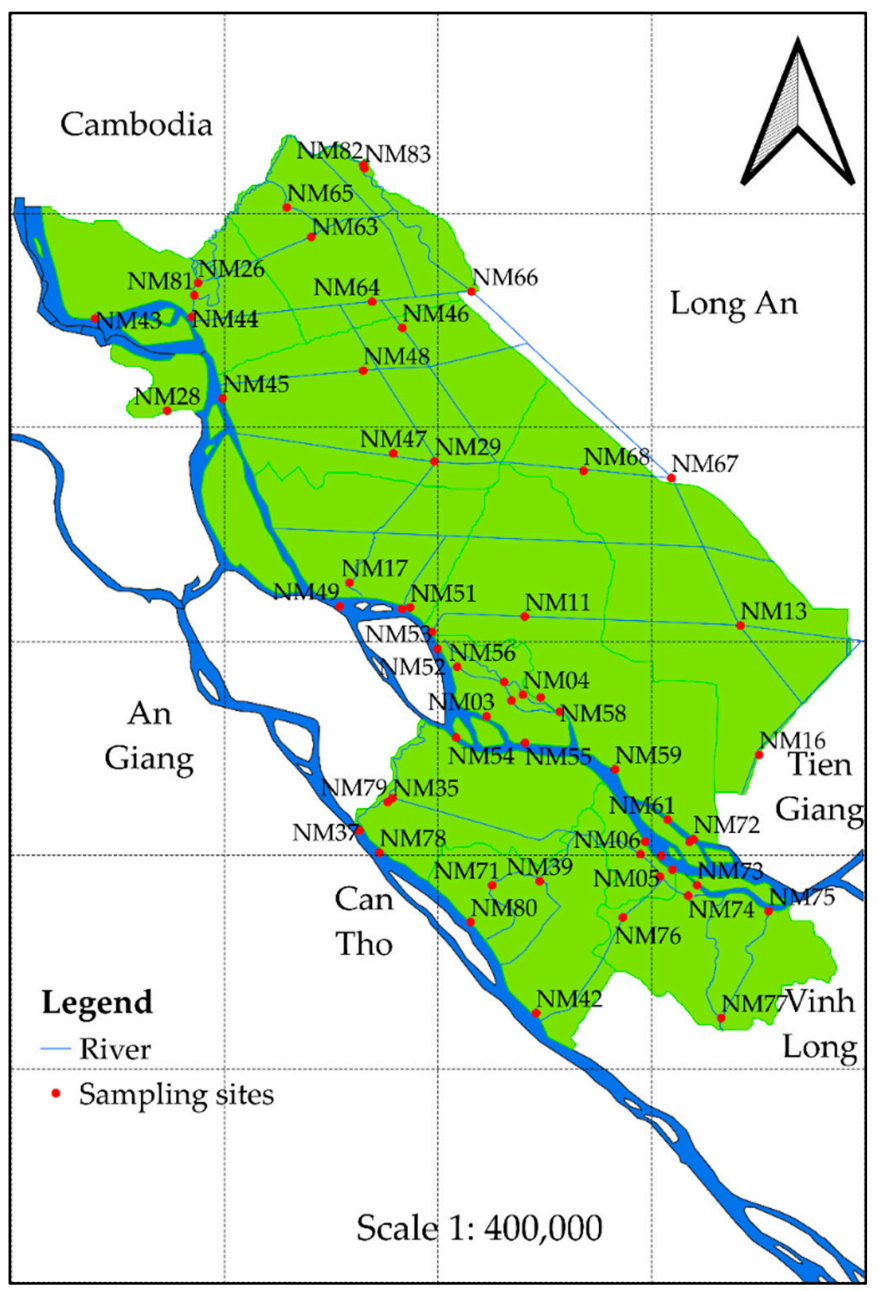

Figure 1. Demonstration of the water sampling sites in Dong Thap province in 2019.

The parameters used to calculate WQI in the guidance of the Vietnam Environment Administration in 2019 are divided into 05 groups of parameters, including the $\mathrm{pH}$ parameter group, the pesticide parameter group (09 parameters), the heavy metal parameter group (07 parameters), the organic and nutritional parameter group (08 parameters), and the microbiological parameter group (02 parameters). These parameters needed to satisfy two conditions: (1) at least 03/05 parameter groups must be included in the calculation, (2) the group of organic and nutritional parameters must have at least 03 parameters. Therefore, the data set in the study ensured the conditions for calculating the WQI value. However, based on the guidance of the Vietnam Environment Administration, the parameters turbidity, TSS, $\mathrm{Cl}^{-}, \mathrm{SO}_{4}{ }^{2-}, \mathrm{TN}, \mathrm{TP}$, and oil and grease were not calculated; therefore, the calculated data set included only 10/17 analyzed parameters.

WQI values were calculated by the formula (1):

$$
\begin{aligned}
& \mathrm{WQI}=\frac{\mathrm{WQI}_{\mathrm{pH}}}{100} \times\left[\frac{1}{2} \times \sum_{\mathrm{a}=1}^{7} \mathrm{WQI}_{\mathrm{a}} \times \sum_{\mathrm{b}=1}^{2} \mathrm{WQI}_{\mathrm{b}}\right]^{1 / 2} \\
& \mathrm{WQI}=\frac{\mathrm{WQI}_{\mathrm{pH}}}{100}\left[\frac{1}{2} \sum_{\mathrm{a}=1}^{2} \mathrm{WQI}_{\mathrm{a}} \cdot \mathrm{WQI}_{\mathrm{b}}\right]^{1 / 2}
\end{aligned}
$$

where $\mathrm{WQI}_{\mathrm{a}}$ is the calculated WQI value for parameters $\mathrm{DO}, \mathrm{BOD}, \mathrm{COD}, \mathrm{N}-\mathrm{NH}_{4}{ }^{+}, \mathrm{N}-$ $\mathrm{NO}_{2}{ }^{-}, \mathrm{N}-\mathrm{NO}_{3}{ }^{-}, \mathrm{P}^{-} \mathrm{PO}_{4}{ }^{3-} ; \mathrm{WQI}_{\mathrm{b}}$ is the calculated WQI value for coliforms and E. coli, and $\mathrm{WQI}_{\mathrm{pH}}$ is the calculated value for $\mathrm{pH}$. The results of WQI value can provide general information on suitable water uses at the monitoring sites. 
Pearson correlation analysis is a preliminary descriptive technique to estimate the degree of association among multiple variables involved in the study. The following formula is used to calculate the Pearson correlation (2):

$$
r=\frac{\sum_{i=1}^{n}\left(X_{i}-\bar{X}\right) \times\left(Y_{i}-\bar{Y}\right)}{\sqrt{\sum_{i=1}^{n}\left(X_{i}-\bar{X}\right)^{2}} \times \sqrt{\sum_{i=1}^{n}\left(Y_{i}-\bar{Y}\right)^{2}}}
$$

In which:

$r=$ Pearson $r$ correlation coefficient between parameter $X$ and parameter $Y$.

$n=$ number of observations.

$X_{i}=$ value of $X$ (for ith observation).

$Y_{i}=$ value of $Y$ (for ith observation).

These values vary from -1 to 1 , and the sign of each correlation coefficient indicates the inverse correlation between the parameters. The greater correlation occurs if the coefficient approaches -1 or 1 . The correlation is moderate when its coefficient has absolute value $>|0.3|-|0.5|$; correlations higher than 0.5 considered strong; in contrast, its correlation is low when the correlation coefficient has absolute value $<|0.3|[18,19]$.

Principal component analysis (PCA) was used to determine the main water parameters in the variation of the data set. This method enables us to reduce baseline parameters that do not make a significant contribution to data variability while creating a new set of parameters called key component or factor (PC). The eigenvalue coefficient of each factor is used to decide the main components. The larger this coefficient is, the greater the contribution to interpreting the variation of the original dataset. The method used in PCA is Varimax, and each initial data variable is classified as a factor, and each factor represents a subset of the initial variables. Correlations between the main component and the primary data variables are indicated by the weighted correlation coefficients [11].

In addition, cluster analysis (CA) was performed to group the locations based on the similarity of water properties. The analysis does not give any assumptions about the similarity of the positions; the clusters are formed statistically at $D_{\text {link }} / D_{\max } \times 100<60$, in which $\mathrm{D}_{\text {link}}$ : linkage distance for an individual case and $\mathrm{D}_{\max }$ : maximum linkage distance. The number of clusters is determined by the fact of this study. Ward method and Euclidean range were used as measures of similarity [10]. CA and PCA were performed using copyrighted software Primer 5.2 for Windows (PRIMER-E Ltd., Plymouth, UK).

\section{Results and Discussion}

\subsection{Summary of Surface Water Quality in Dong Thap Province in 2019}

The mean water temperature in 2019 ranged from $29.56 \pm 1.05^{\circ} \mathrm{C}$ to $31.08 \pm 1.09{ }^{\circ} \mathrm{C}$ (Figure 2). ANOVA analysis showed a statistically significant difference in temperature between the observed months $(p<0.05)$. The temperature recorded in November was higher than that in February, May, and August. According to previous studies, there was no significant difference in water temperature in Bung Binh Thien, canals in An Giang, and main rivers and tributaries of Can Tho province compared to the study area [20-22]. It can be caused by water regulates the temperature in water, mostly in large deep canals or rivers.

The $\mathrm{pH}$ values had a statistically significant difference between wet season (May, August) and dry season (February, November) $(p<0.05)$. This is consistent with the seasonal distribution of $\mathrm{pH}$ in the Mekong Delta regions. Intermonth $\mathrm{pH}$ values ranged from $7.15 \pm 0.20$ to $7.36 \pm 0.27$ (Figure 2), which was also reported in similar water bodies and were within the allowable range of QCVN 08-MT: 2015/BTNMT (6.5-8.5) [20-22].

Turbidity was seasonally varied through February, May, August, and November, with average values of $26.63 \pm 9.47 \mathrm{NTU}, 63.98 \pm 20.78 \mathrm{NTU}, 59.86 \pm 10.49 \mathrm{NTU}$, and $44.42 \pm 13.13 \mathrm{NTU}$, respectively. The results showed a statistically significant difference $(p<0.05)$ between May versus February and November. In contrast, there was no difference between May and August $(p>0.05)$ (Figure 2). High turbidity during the rainy season can 
be caused by water runoff due to frequent and heavy rainfall. During the rainy season, the upstream sedimentation coupled with the precipitation eroded on both sides of the river can increase turbidity at this time [23]. In addition, organic impurities, insoluble inorganics, and micro-planktons have also resulted in high turbidity. The previous studies have also reported that the water turbidity varied considerably between the surveys $[20,24,25]$.
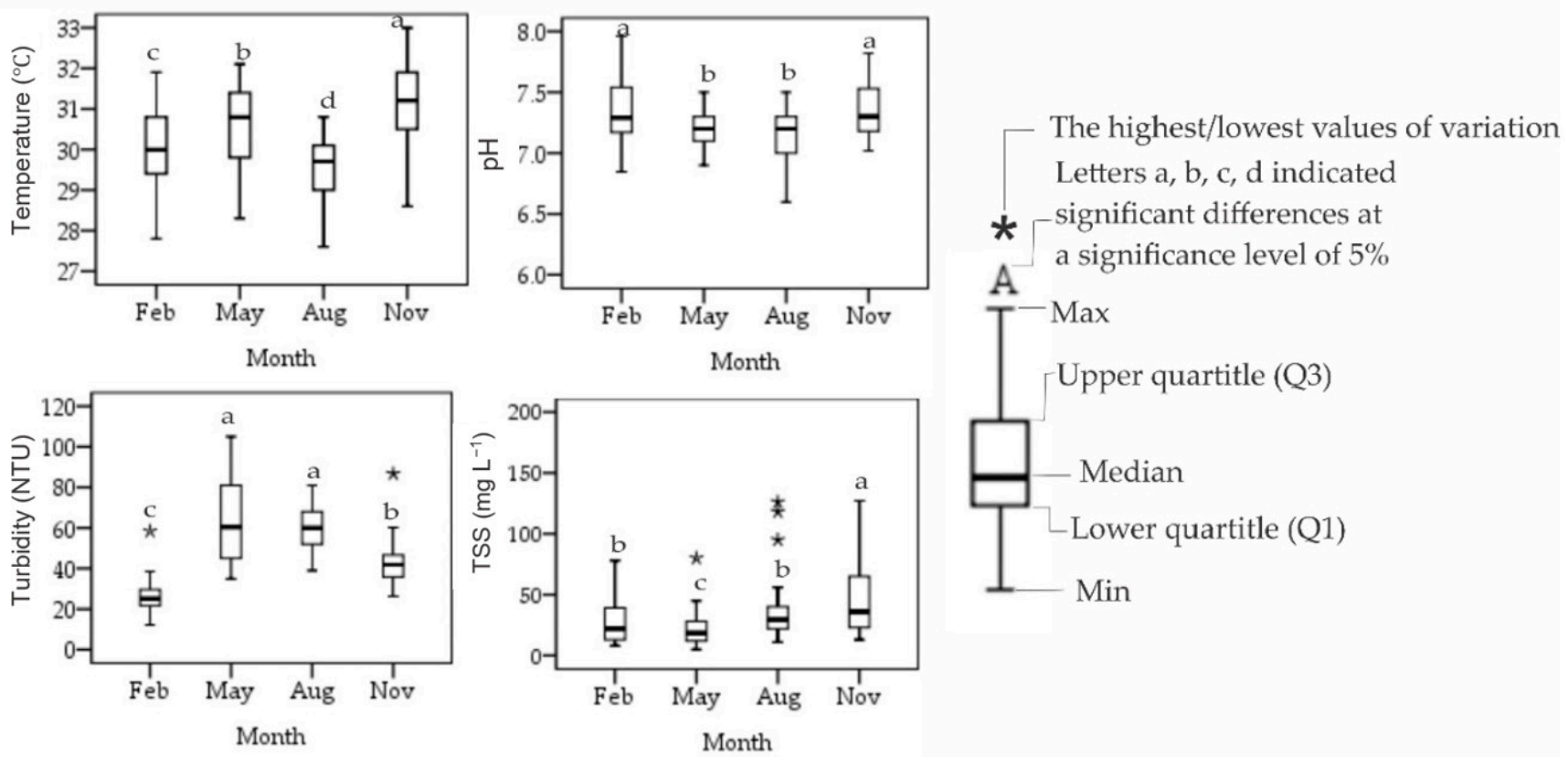

Figure 2. General conditions of water quality parameters in Dong Thap province in 2019.

Moreover, the concentration of suspended clay particles also affects the TSS in the water. TSS formed by plankton is beneficial, and that of suspended clay particles are detrimental. In the study, TSS also had a considerable seasonal variation, ranging from $21.71 \pm 15.11$ to $49.57 \pm 33.58 \mathrm{mg} \mathrm{L}^{-1}$, and the difference was statistically significant $(p<0.05)$. According to the value specified in QCVN 08-MT: 2015/BTNMT, column A2 (30 $\mathrm{mg} \mathrm{L}^{-1}$ ), which was used for the purpose of domestic water supply but applying the appropriate treatment technology or irrigation and drainage and water transportation, TSS exceeded the specified limit (except in May). However, TSS in the present study tended to be lower than those reported in the previous studies [21,22] in the canals and rivers in An Giang and Can Tho provinces. TSS had the difference between the monitoring months because the amount of water flowing and flooding from upstream carrying various amounts of sediments led to high TSS concentrations. The high amount of TSS can increase treatment costs and make the aquatic environment less suitable for living.

The mean DO concentrations in February, May, August, and November were $5.07 \pm$ $0.63 \mathrm{mg} \mathrm{L}^{-1}, 5.13 \pm 0.12 \mathrm{mg} \mathrm{L}^{-1}, 5.16 \pm 0.15 \mathrm{mg} \mathrm{L}^{-1}$, and $5.18 \pm 0.33 \mathrm{mg} \mathrm{L}^{-1}$, respectively. The difference was not statistically significant between the observed months $(p>0.05)$ (Figure 3). DO concentration tended to increase in the observation months. This could be due to the diffusion directly from the air by disturbance or produced by phytoplankton through photosynthesis. The DO was assessed to meet the limit of QCVN 08-M: 2015/BTNMT column A2 (5 mg L $\left.{ }^{-1}\right)$. However, the DO concentrations in this study were found to be higher than those in the water bodies in An Giang (4.0-5.2 $\mathrm{mg} \mathrm{L}^{-1}$ ) [21] and Can Tho (3.5-5.8 $\mathrm{mg} \mathrm{L}^{-1}$ ) [26]. The low DO in An Giang and Can Tho could be due to the presence of biodegradable matters, fertilizers from agricultural land [21,27]. DO may not pose a direct hazard to human health, but it may affect other chemicals in the water [27]. Typically, BOD and COD in the months of the year 2019 ranged from $14.05 \pm 1.41-15.52 \pm 1.67 \mathrm{mg} \mathrm{L}^{-1}$ and $21.26 \pm 1.74-23.03 \pm 1.77 \mathrm{mg} \mathrm{L}^{-1}$ (Figure 3). Furthermore, ANOVA analysis showed that BOD was significantly different $(p<0.05)$ between August compared to February, May, 
and November; however, there was no difference between February, May, and November $(p>0.05)$. Similarly, COD levels were significantly different between February, August, and November $(p<0.05)$. The difference between BOD and COD can be assessed as negligible; it means that the organic matter in the water body is mainly biodegradable organic matter. BOD and COD exceeded the allowable limits of QCVN 08-MT: 2015/BTNMT, column A2, with the limit values of $6 \mathrm{mg} \mathrm{L}^{-1}$ and $15 \mathrm{mg} \mathrm{L}^{-1}$, respectively; which showed that the quality of water was organically polluted.
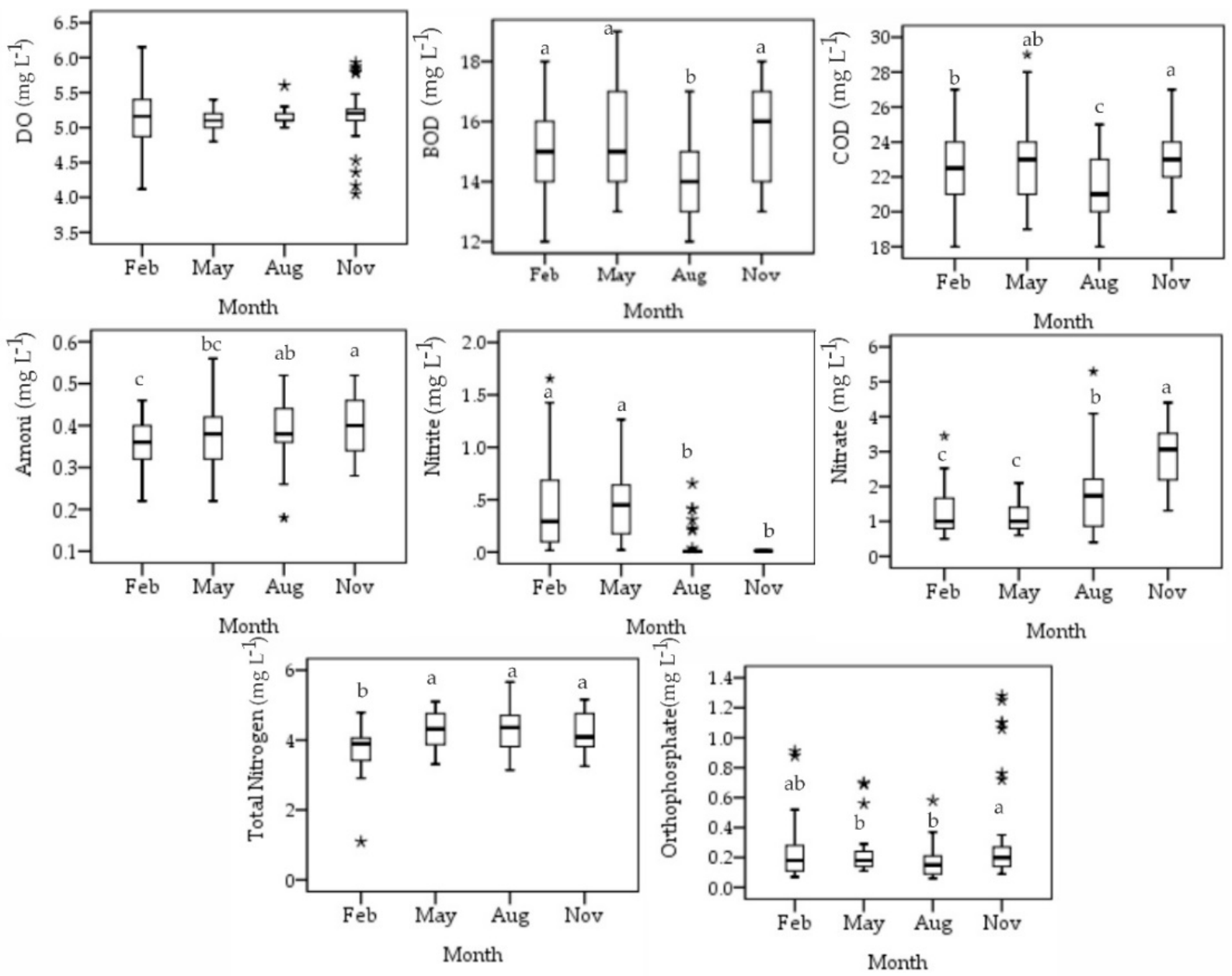

Figure 3. Oxygenation and nutrient parameters of water in Dong Thap province in 2019. Note: * the highest/lowest values of variation; Letters a, b, c indicated significant differences at a significance level of $5 \%$; in contrast, the same letters have no statistically significant difference.

$\mathrm{N}-\mathrm{NH}_{4}{ }^{+}$over the observation months tended to increase through the survey periods and fluctuated between $0.36 \pm 0.061$ and $0.40 \pm 0.074 \mathrm{mg} \mathrm{L}^{-1}$, and the difference was statistically significant between February and November $(p<0.05)$ (Figure 3$)$. $\mathrm{N}_{-} \mathrm{NH}_{4}{ }^{+}$ concentration exceeded the prescribed limit of QCVN 08-MT: 2015/TNMT, which indicated that surface water quality in the water body was contaminated with nutrients. Moreover,

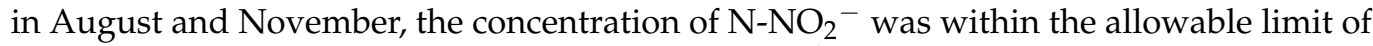
QCVN 08-MT: 2015/BTNMT, column A2 $\left(0.05 \mathrm{mg} \mathrm{L}^{-1}\right)$. In contrast, the concentration of $\mathrm{N}$ $\mathrm{NO}_{2}{ }^{-}$in February $\left(0.46 \mathrm{mg} \mathrm{L}^{-1}\right)$ and May $\left(0.46 \mathrm{mg} \mathrm{L}^{-1}\right)$ were determined to be higher than the permissible limit of QCVN 08-MT: 2015/BTNMT, column A2 $\left(0.05 \mathrm{mg} \mathrm{L}^{-1}\right)$, with the levels of 9.2 times and 9.1 times, respectively. In addition, the study also noted a statistically significant difference between February and May compared with August and November $(p<0.05) ; \mathrm{N}^{-\mathrm{NO}_{2}}{ }^{-}$concentrations in the months of the rainy season were higher than those in the months of the dry season. The increase of $\mathrm{N}^{-\mathrm{NO}_{2}}{ }^{-}$can be explained by the nitrogen 
of wastewater and insufficient DO in converting $\mathrm{N}^{-\mathrm{NO}_{2}}{ }^{-}$into $\mathrm{N}-\mathrm{NO}_{3}{ }^{-}$by nitrifying microorganisms. Another explanation for this might be the consequences of fertilizers. $\mathrm{N}-\mathrm{NO}_{2}{ }^{-}$was a product of nitrification and denitrification, and $\mathrm{N}^{-N^{-}}{ }_{2}{ }^{-}$can be toxic to

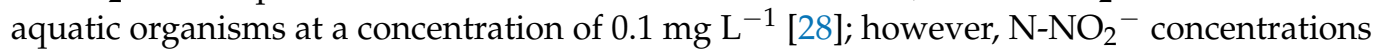
in February and May were recorded to be 4.59 times higher than that level. Water containing $\mathrm{N}-\mathrm{NO}_{2}{ }^{-}$is of great concern because it can cause methemoglobinemia or blue-skin disease due to limited oxygen transport in the bloodstream. In contrast to $\mathrm{N}_{-} \mathrm{NO}_{2}{ }^{-}, \mathrm{N}^{-} \mathrm{NO}_{3}{ }^{-}$ concentrations tended to be the highest in November of $3.00 \pm 0.83 \mathrm{mg} \mathrm{L}^{-1}$ and lowest in May at $1.14 \pm 0.39 \mathrm{mg} \mathrm{L}^{-1}$. The results of the statistical analysis showed a significant difference $(p<0.05)$ between May and November (Figure 3). This difference has also been reported in several water bodies in the past, where $\mathrm{N}_{-} \mathrm{NO}_{3}{ }^{-}$concentration was high in October, November, and December and low in April, May, and June. It is explained by decreased biological activities (bacterial denitrification and algae assimilation) in the last months of the year. However, most of the monitoring months in the study area were within the allowable limits of QCVN 08-MT: 2015/BTNMT column A2 (5 mg L $\left.{ }^{-1}\right)$. Meanwhile, TN fluctuated to relatively high degree from $3.75 \pm 0.54$ to $4.30 \pm 0.51 \mathrm{mg} \mathrm{L}^{-1}$, and the difference was statistically significant $(p<0.05)$ between May, August, November compared to February (Figure 3). To minimize the ability to cause water eutrophication, TN should not exceed $1.5 \mathrm{mg} \mathrm{L}^{-1}$ [29]. When TN is higher than $1.7 \mathrm{mg} \mathrm{L}^{-1}$, the ability to cause water eutrophication is very high [30]. This point shows that the concentration of TN through the monitoring phases can potentially cause eutrophication.

In addition, the $\mathrm{P}_{-} \mathrm{PO}_{4}{ }^{3-}$ in February, May, August, and November were $0.24 \pm$ $0.18 \mathrm{mg} \mathrm{L}^{-1}, 0.21 \pm 0.12 \mathrm{mg} \mathrm{L}^{-1}, 0.18 \pm 0.11 \mathrm{mg} \mathrm{L}^{-1}$, and $0.30 \pm 0.30 \mathrm{mg} \mathrm{L}^{-1}$, respectively, which was a statistically significant difference $(p<0.05)$ between November versus May and August. There was no difference between November and February $(p>0.05)$ (Figure 3). The content of $\mathrm{P}_{-} \mathrm{PO}_{4}{ }^{3-}$ in February and November was higher than that of QCVN 08MT:2015/BTNMT, around 1.2-1.5 times. Normally, phosphorus dissolved in natural surface water is found in concentrations ranging from 0.005 to $0.02 \mathrm{mg} \mathrm{L}^{-1}$ and greater than $0.02 \mathrm{mg} \mathrm{L}^{-1}$, which is considered nutritious [31]. Similar to TN, P-PO ${ }_{4}{ }^{3-}$ could result in potential eutrophication in surface water in Dong Thap province.

$\mathrm{Cl}^{-}$and $\mathrm{SO}_{4}{ }^{2-}$ concentrations had similar fluctuations over the survey periods, ranging from $7.26 \pm 3.19$ to $19.48 \pm 7.80 \mathrm{mg} \mathrm{L}^{-1}$ and $18.04 \pm 11.43$ to $28.65 \pm 3.77 \mathrm{mg} \mathrm{L}^{-1}$, respectively. The results showed a statistically significant difference $(p<0.05)$ between November versus May and February versus August; however, there was no difference between February and August. Similarly, $\mathrm{SO}_{4}{ }^{2-}$ concentration was a statistically significant difference between May versus August or May versus February and November $(p<0.05)$. Compared with the study of Truc et al. (2019) [32] on the surface water quality of the Tien River flowing through Tan Chau, An Giang's lowest $\mathrm{Cl}^{-}$value was found in August 2017 (2.1 mg L $\mathrm{mg}^{-1}$, while the highest value was measured in December 2017 (19.4 mg L $\left.{ }^{-1}\right)$. Concentrations of $\mathrm{SO}_{4}{ }^{2-}$ in the study's water bodies in February and November were lower than those in May and August, possibly due to the use of sulfate by some microorganisms as dissolved oxygen sources. Additionally, when sulfate concentrations ranged from $5.3 \pm 8.1$ to $27.8 \pm 5.3 \mathrm{mg} \mathrm{L}^{-1}$ in river water [13], the water bodies were influenced by several human activities. In this study, $\mathrm{Cl}^{-}$and $\mathrm{SO}_{4}{ }^{2-}$ concentrations were significantly detected in surface water, which could have originated from human activities; therefore, it needs to be appropriately treated for meeting domestic use and other similar purposes.

The mean density of coliforms in the monitoring months ranged from $4599.31 \pm 3019.32$ to $8327.41 \pm 7685.89 \mathrm{MPN} 100 \mathrm{~mL}^{-1}$ (Figure 4). This density was statistically significantly different between February and August and November $(p<0.05)$. An increase in coliform density with increasing temperature was also previously reported [33], which can be explained for the maximum coliform density in August (8327.41 \pm 7685.89 MPN $100 \mathrm{~mL}^{-1}$ ). According to the limit value of coliform in QCVN 08-MT: 2015/BTNMT, column A2 (5000 MPN $100 \mathrm{~mL}^{-1}$ ), coliform density in the study area exceeded the permitted limit in May, August, and November by approximately 1.3-1.4 times. However, 
coliform density in the water bodies in Dong Thap was significantly lower than that in An Giang and Can Tho $[21,22,26]$. The main reason why the density of coliform is more contaminated in An Giang and Can Tho is the presence of artificial waste such as point sources (domestic, industrial, aquaculture) and non-point sources (soil leaching, grazing), as well as other environmental factors such as temperature, $\mathrm{pH}$, salinity, turbidity, nutrients, and hydrological regime $[34,35]$. In Dong Thap, the source of pollution mainly comes from domestic, soil washout and grazing, while An Giang and Can Tho are mainly derived from domestic and industry. Considering some environmental factors, the values of $\mathrm{pH}$ and DO in the An Giang and Can Tho watersheds are more favorable for the development of coliform than Dong Thap.
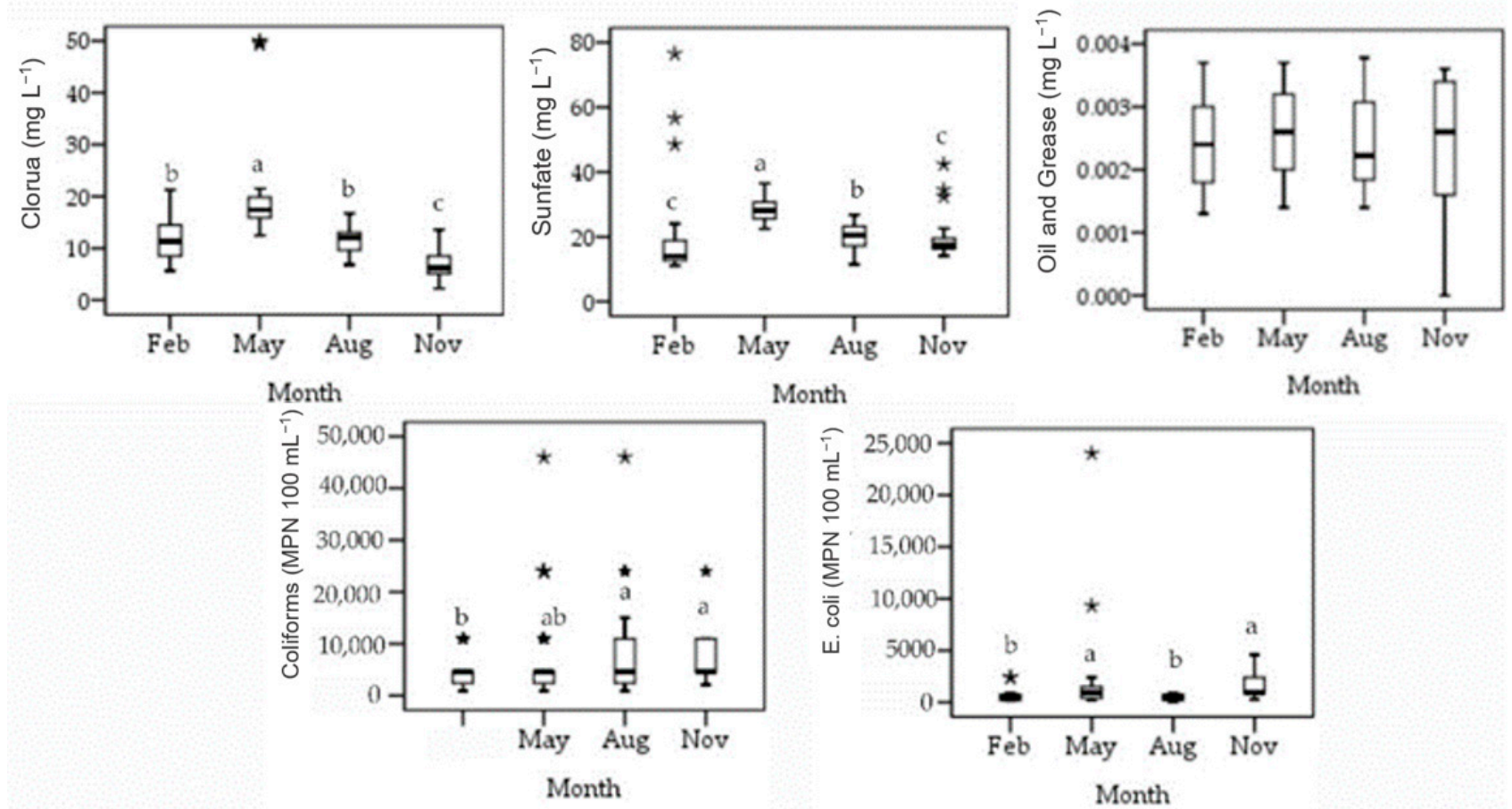

Figure 4. Microbial and ions variables of water in Dong Thap province in 2019. Note: * the highest/lowest values of variation; Letters a, b, c indicated significant differences at a significance level of $5 \%$; in contrast, the same letters have no statistically significant difference.

The average density of $E$. coli in the study area was very high and seasonally fluctuated. Specifically, E. coli density was significantly different $(p<0.05)$ in the two months of the rainy season (May and August) and the two months of the dry season (February and November). The density of E. coli in February, May, August, and November was $548.10 \pm 430.41$, $1728.97 \pm 3320.80 \mathrm{MPN} 100 \mathrm{~mL}^{-1}, 520.26 \pm 438.64 \mathrm{MPN} 100 \mathrm{~mL}^{-1}$, and $1615.17 \pm 1124.19$ MPN $100 \mathrm{~mL}^{-1}$, respectively (Figure 4). This shows that E. coli in the rainy season was higher than that in the dry season. Compared with QCVN 08-MT: 2015/BTNMT, E. coli at all monitoring months exceeded the allowable limit of column A2 by $10-34$ times. This indicator can be considered as the most exceeding parameter. Therefore, the water quality in water bodies in Dong Thap province has high risk for human uses. Appropriate measures are urgently needed to treat and improve the existing water resources.

Meanwhile, oil and grease concentration over the observed months were relatively low, and there was no statistically significant difference $(p>0.05)$, ranging from $0.0024 \pm 0.00072$ to $0.0027 \pm 0.00076 \mathrm{mg} \mathrm{L}^{-1}$ (Figure 4). The above results show that the concentration of oil and grease did not fluctuate greatly among seasons and were within the limit of QCVN 08-MT: 2015/BTNMT, column A2. The concentration of oil and grease in the surface water was mainly from domestic waste and leaching of materials; Nevertheless, this content 
was negligible. On the other hand, the algae absorption can be attributed to the low concentration of oil and grease in the water due to its susceptible to biological oxidation.

In short, the surface water quality in Dong Thap province in 2019 was polluted by suspended solids, organic matters, nutrients, and microbes. This indicated that the potential risk of eutrophication is very high, which is a leading cause of impairment of many freshwater ecosystems and human health. Therefore, it is necessary to develop appropriate programs to tackle these current problems.

\subsection{Correlation among Water Quality Variables in Water Bodies in Dong Thap Province in 2019}

The correlation between 17 observed indicators at 58 sampling locations along Tien River, Hau River, and infield canals in Dong Thap province in 2019 is presented in Table 1. The results show that temperature was positively correlated with BOD, COD, TSS, and $\mathrm{N}^{-\mathrm{NO}_{3}}{ }^{-}$and inversely correlated with DO. It was shown that the higher the temperature is, the more likely that the water is saturated [36,37]. The study also recorded that the $\mathrm{pH}$ parameter had a low negative correlation with $\mathrm{Cl}^{-}(\mathrm{r}=0.15)$, turbidity $(\mathrm{r}=0.26)$, and $\mathrm{SO}_{4}{ }^{2-}(\mathrm{r}=0.27)$. In practice, turbidity is related to runoff water and soil erosion; however, the $\mathrm{pH}$ is also related to the leaching of compounds containing $\mathrm{Cl}^{-}$and $\mathrm{SO}_{4}{ }^{2-}$. An inverse correlation between $\mathrm{pH}$ and turbidity has also been noted in a previous study [12]. Meanwhile, turbidity was found to positively correlate with TSS, $\mathrm{Cl}^{-}, \mathrm{SO}_{4}{ }^{2-}$, and TN. This can be seen that the water in the study area contained several dissolved ions, especially fertilizers containing sulfur and chlorine [38].

TSS showed a positive correlation with several parameters such as $\mathrm{N}-\mathrm{NO}_{3}{ }^{-}, \mathrm{P}_{-} \mathrm{PO}_{4}{ }^{3-}$,

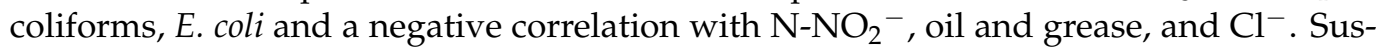
pended solids in water tended to adsorb $\mathrm{P}_{-} \mathrm{PO}_{4}{ }^{3-}$ and $\mathrm{N}-\mathrm{NO}_{3}{ }^{-}$[39]. Similarly, the correlation of TSS with coliform and E. coli was explained by soil leaching in the husbandry areas, resulting in increased TSS, coliforms, and E. coli. Therefore, the reduction in E. coli density and nutrients in water can be accomplished by sedimentation with clay particles. In addition, stormwater runoff with non-volatile hydrocarbons, animal and vegetable oils, grease, and other related materials can increase the grease contents in the water body [40]. This amount of grease can stick to the soil particles during leaching and floating on the water surface, limiting the number of suspended solids present in the water.

Moreover, a high DO may increase the nitrification rate [12,41]. It helps to explain the positive correlation between $\mathrm{DO}$ and $\mathrm{N}-\mathrm{NO}_{3}{ }^{-}$in this study. BOD correlated positively with COD at a high level $(\mathrm{r}=0.84)$. There was no statistically significant difference between these two parameters, meaning that most organic matters were quickly biodegradable.

$\mathrm{N}-\mathrm{NO}_{3}{ }^{-}$was positively correlated with $\mathrm{P}_{-} \mathrm{PO}_{4}{ }^{3-}$ and inversely correlated with N$\mathrm{NO}_{2}{ }^{-}$and $\mathrm{Cl}^{-}$. There was a correlation between $\mathrm{N}-\mathrm{NO}_{3}{ }^{-}$with $\mathrm{Cl}^{-}$and $\mathrm{P}_{-} \mathrm{PO}_{4}{ }^{3-}$ at an average correlation level and $\mathrm{N}_{-} \mathrm{NO}_{2}{ }^{-}$at a weak correlation level. It was expected that there was an inverse correlation between $\mathrm{N}-\mathrm{NO}_{3}{ }^{-}$and $\mathrm{N}-\mathrm{NO}_{2}{ }^{-}$because the $\mathrm{N}-\mathrm{NO}_{3}{ }^{-}$ concentration depends on the nitrification process. Furthermore, there is a moderate positive correlation between $\mathrm{Cl}^{-}$and $\mathrm{SO}_{4}{ }^{2}$, related to the water-soluble salts in the study water body. This correlation has also been determined in a previous study [42].

Furthermore, coliform correlated with E. coli at a strong positive correlation. Water quality has been significantly influenced by the residential areas [43] because E. coli is derived from the human digestive system. For $\mathrm{N}_{-} \mathrm{NH}_{4}{ }^{+}$, no correlation with other parameters was noted. Overall, the results indicated that most of the water quality parameters were correlated. However, the correlation between water quality parameters is only a medium-weak correlation. Therefore, the parameters at the study water bodies may have been greatly influenced by external environmental factors. 
Table 1. Correlation among water variables in water bodies in Dong Thap province.

\begin{tabular}{|c|c|c|c|c|c|c|c|c|c|c|c|c|c|c|c|c|c|}
\hline Var. & Temp. & $\mathrm{pH}$ & Turb & TSS & DO & BOD & COD & $\mathrm{N}-\mathrm{NH}_{4}{ }^{+}$ & $\mathrm{N}-\mathrm{NO}_{2}{ }^{-}$ & $\mathrm{N}-\mathrm{NO}_{3}^{-}$ & $\mathrm{TN}$ & ${\mathrm{P}-\mathrm{PO}_{4}}^{3-}$ & $\mathrm{Cl}^{-}$ & $\mathrm{SO}_{4}{ }^{2-}$ & Col. & E. coli & $\begin{array}{l}\text { Oil and } \\
\text { Grease }\end{array}$ \\
\hline Temp & 1 & & & & & & & & & & & & & & & & \\
\hline $\mathrm{pH}$ & 0.01 & 1 & & & & & & & & & & & & & & & \\
\hline Turb & -0.01 & -0.27 & 1 & & & & & & & & & & & & & & \\
\hline DO & -0.24 & -0.03 & -0.09 & 0.13 & 1 & & & & & & & & & & & & \\
\hline BOD & 0.26 & 0.01 & 0.01 & -0.04 & -0.05 & 1 & & & & & & & & & & & \\
\hline COD & 0.23 & 0.03 & -0.08 & -0.07 & -0.05 & 0.84 & 1 & & & & & & & & & & \\
\hline $\mathrm{N}-\mathrm{NH}_{4}{ }^{+}$ & 0.04 & 0.07 & 0.02 & -0.01 & 0.05 & 0.02 & 0.04 & 1 & & & & & & & & & \\
\hline $\mathrm{N}-\mathrm{NO}_{2}^{-}$ & -0.07 & -0.10 & -0.11 & -0.15 & 0.07 & 0.10 & 0.08 & -0.10 & 1 & & & & & & & & \\
\hline $\mathrm{N}-\mathrm{NO}_{3}^{-}$ & 0.30 & 0.03 & -0.03 & 0.27 & 0.13 & 0.09 & 0.09 & 0.12 & -0.13 & 1 & & & & & & & \\
\hline $\mathrm{P}^{-\mathrm{PO}_{4}}{ }^{3-}$ & 0.11 & -0.00 & -0.05 & 0.42 & 0.18 & 0.08 & 0.01 & -0.02 & 0.02 & 0.22 & -0.00 & 1 & & & & & \\
\hline $\mathrm{Cl}^{-}$ & -0.03 & -0.15 & 0.33 & -0.16 & -0.03 & 0.06 & -0.02 & -0.10 & 0.34 & -0.28 & 0.06 & -0.02 & 1 & & & & \\
\hline $\mathrm{SO}_{4}{ }^{2-}$ & 0.06 & -0.26 & 0.23 & 0.03 & 0.14 & 0.01 & -0.04 & -0.09 & 0.22 & -0.09 & 0.16 & 0.07 & 0.46 & 1 & & & \\
\hline Col. & -0.02 & -0.03 & 0.00 & 0.34 & 0.03 & -0.09 & -0.06 & 0.07 & -0.06 & 0.07 & 0.08 & 0.04 & 0.02 & 0.06 & 1 & & \\
\hline E. coli & 0.12 & 0.06 & 0.02 & 0.19 & -0.02 & 0.03 & 0.05 & 0.09 & -0.01 & 0.02 & -0.01 & 0.05 & 0.09 & 0.16 & 0.58 & 1 & \\
\hline Oil and Grease & 0.00 & 0.03 & 0.05 & -0.13 & -0.02 & 0.05 & 0.06 & -0.01 & 0.00 & -0.05 & -0.03 & -0.06 & 0.09 & 0.00 & -0.10 & -0.00 & 1 \\
\hline
\end{tabular}

Note: Temp-Temperature; Turb-Turbidity; Col.-Coliform. 


\subsection{Spatial Variation of Water Quality Index in the Water Bodies in Dong Thap Province in 2019}

The mean values of the ten physical and chemical parameters were used to calculate the water quality index (WQI) at 58 locations, which is shown in Figure 5. The results showed that the WQI values at these monitoring sites were from medium (yellow color) to poor (red color). While nine locations were identified with very poor water quality, the poor and medium water quality accounted for 24 monitoring locations at each level. Water quality was unevenly spatially distributed in the study area. Poor water quality was mostly found in the regions associated with concentrated socio-economic activities. Specifically, the southern regions of Dong Thap had lower water quality than those in the northern; the South of Dong Thap has two main rivers Tien and Hau, where they could receive several discharging sources from industrial, domestic, aquacultural, and agricultural activities. In contrast, the water quality in the northern part of Dong Thap may be affected by the flow and discharge characteristics from upstream of Cambodia by the Mekong river system's transboundary character. However, the water quality in Dong Thap was considered to be less polluted than that in the water bodies in An Giang province [15,44]. It was reported that water quality in the southeast region of An Giang had better water quality, which is consistent with the calculation results of WQI in the northwest part of Dong Thap, where the water quality better than that in the other places in the study area. However, water quality was similar to that in Can Tho's water bodies in 2018 [22]. It can be seen that the application of GIS incorporating WQI in surface water quality assessment can be the basis for further considering the surface water monitoring network in Dong Thap province in the future.

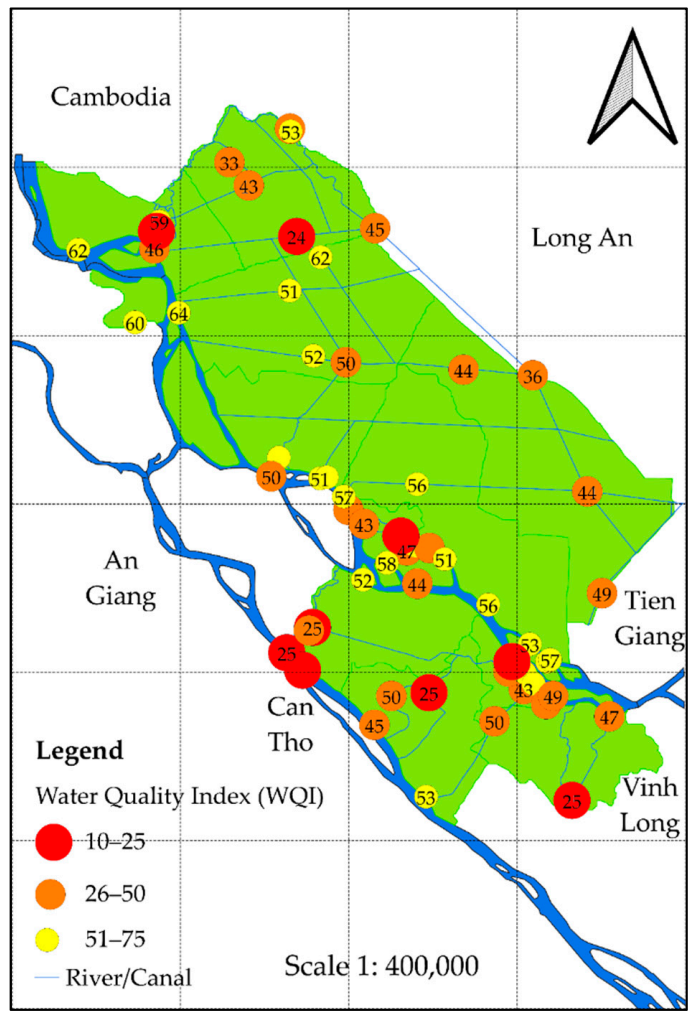

Figure 5. Map of water quality index in water bodies in Dong Thap province in 2019.

3.4. Key Water Variables Influencing Water Quality in the Water Bodies in Dong Thap Province in 2019

The principal component analysis results revealed that 11 PCs contributed significantly and explained $90.7 \%$ of the total variation in surface water quality in Dong Thap province in 2019 (Table 2). For the extraction of each component in the PCA analysis, the eigenvalue coefficient was used as a criterion to determine the load or importance 
level of each component [45]. PC1 and PC2 contributed, respectively, $17.5 \%$ and $13.9 \%$ of surface water quality variation while PC3, PC4, PC5, PC6, PC7, PC8, PC9, PC10, and PC11 contributed $10.4 \%, 9.5 \%, 7.7 \%, 7 \%, 6.9 \%, 5.1 \%, 4.9 \%, 4.6 \%$, and $3.4 \%$, respectively. Eigenvalues coefficients greater than 1 are considered significant and vice versa [14,46]. In this study, the eigenvalues from PC1 to PC7 were greater than 1, so these PCs were used to evaluate potential polluting sources and key water quality variables in the present study. It can be seen that the change of water quality in Dong Thap province in 2019 was very complicated and affected by various pollution sources.

Table 2. PCA for water quality data in the water quality in Dong Thap province in 2019.

\begin{tabular}{|c|c|c|c|c|c|c|c|c|c|c|c|}
\hline Parameters & PC1 & PC2 & PC3 & PC4 & PC5 & PC6 & PC7 & PC8 & PC9 & PC10 & PC11 \\
\hline Temperature & 0.00 & 0.38 & -0.04 & -0.21 & -0.34 & 0.34 & 0.20 & 0.33 & -0.08 & 0.25 & -0.01 \\
\hline $\mathrm{pH}$ & 0.13 & -0.33 & -0.02 & -0.22 & 0.23 & 0.04 & 0.23 & 0.32 & -0.33 & 0.56 & -0.10 \\
\hline Turbidity & 0.07 & -0.09 & 0.54 & -0.22 & -0.08 & -0.15 & 0.02 & -0.30 & -0.46 & -0.05 & 0.02 \\
\hline TSS & -0.41 & 0.06 & 0.23 & -0.22 & -0.06 & 0.05 & -0.22 & 0.15 & -0.02 & -0.14 & 0.12 \\
\hline $\mathrm{DO}$ & -0.18 & -0.36 & -0.08 & 0.29 & 0.33 & -0.18 & -0.20 & 0.25 & 0.22 & 0.20 & 0.08 \\
\hline BOD & 0.27 & 0.40 & 0.29 & 0.02 & 0.28 & -0.26 & -0.05 & 0.10 & 0.10 & 0.10 & 0.12 \\
\hline COD & 0.29 & 0.43 & 0.16 & 0.12 & 0.26 & -0.28 & -0.03 & 0.03 & 0.06 & 0.15 & 0.03 \\
\hline $\mathrm{N}-\mathrm{NH}_{4}{ }^{+}$ & -0.96 & 0.16 & -0.14 & -0.02 & 0.40 & 0.44 & 0.15 & -0.57 & 0.03 & 0.32 & 0.08 \\
\hline $\mathrm{N}^{-\mathrm{NO}_{2}}{ }^{-}$ & -0.22 & 0.08 & -0.07 & 0.62 & 0.04 & -0.23 & 0.27 & 0.14 & -0.56 & -0.06 & -0.14 \\
\hline $\mathrm{N}-\mathrm{NO}_{3}{ }^{-}$ & -0.20 & 0.32 & 0.03 & 0.37 & 0.11 & 0.29 & 0.24 & 0.24 & -0.01 & -0.18 & -0.01 \\
\hline TN & 0.02 & -0.01 & -0.06 & 0.19 & -0.50 & -0.38 & 0.43 & -0.17 & 0.35 & 0.31 & -0.03 \\
\hline P-PO ${ }_{4}^{3-}$ & -0.19 & -0.10 & 0.52 & -0.02 & -0.03 & 0.17 & 0.06 & 0.27 & 0.28 & 0.21 & 0.25 \\
\hline $\mathrm{Cl}^{-}$ & -0.29 & -0.07 & 0.41 & 0.12 & 0.10 & 0.04 & 0.17 & -0.18 & 0.21 & 0.03 & -0.66 \\
\hline $\mathrm{SO}_{4}^{2-}$ & -0.37 & 0.06 & 0.05 & 0.28 & -0.16 & -0.09 & -0.11 & -0.24 & -0.18 & 0.28 & 0.51 \\
\hline Coliforms & -0.36 & 0.24 & -0.20 & -0.36 & 0.15 & -0.26 & 0.01 & 0.10 & 0.07 & -0.04 & -0.14 \\
\hline E. coli & -0.38 & 0.15 & -0.16 & -0.37 & 0.13 & -0.31 & 0.04 & -0.07 & 0.00 & 0.10 & 0.00 \\
\hline Oil and Grease & -0.02 & 0.20 & -0.04 & 0.16 & -0.26 & 0.06 & -0.66 & -0.01 & -0.12 & 0.40 & -0.40 \\
\hline Eigenvalues & 2.97 & 2.37 & 1.76 & 1.61 & 1.31 & 1.18 & 1.17 & 0.87 & 0.84 & 0.79 & 0.57 \\
\hline \%Variation & 17.50 & 13.90 & 10.40 & 9.50 & 7.70 & 7.00 & 6.90 & 5.10 & 4.90 & 4.60 & 3.40 \\
\hline Cum.\%Variation & 17.50 & 31.40 & 41.80 & 51.20 & 58.90 & 65.90 & 72.80 & 77.90 & 82.80 & 87.40 & 90.70 \\
\hline
\end{tabular}

PC1 was the most important factor $(17.5 \%)$ in the contribution of the water quality parameters such as TSS, $\mathrm{SO}_{4}{ }^{2-}$, coliforms, and E. coli at low correlation level and N$\mathrm{NH}_{4}{ }^{+}$at the high level. The present conditions suggested that the cause could be an increase in manure-containing waste, overuse of fertilizers, or disturbance to the flow. TSS could be from surface water runoff, riverbank erosion, and phytoplankton occurrence due to the high risk of eutrophication area. PC2 also significantly explained the variation $(13.9 \%)$ of water quality, in which temperature, $\mathrm{DO}, \mathrm{pH}, \mathrm{BOD}, \mathrm{COD}$, and $\mathrm{N}_{-} \mathrm{NO}_{3}{ }^{-}$were the parameters causing the most considerable fluctuation. This component can be from hydrological conditions, domestic, urban, and agricultural sources. Hydrological factors mainly affect the self-cleaning process of rivers/canals, including flow velocity, fluctuation in water level, water temperature, flow rate, and catchment area. Typically, large bodies of water and deep water can promote disturbance and self-cleaning, which can directly affect the temperature and aquatic ecosystems, indirectly affecting the process of oxygen exchange in the water. The inverse correlation of temperature and DO, and DO with BOD and COD could mean that as temperature increases, $\mathrm{DO}$ decreases, and BOD and COD increase [14,47]. The fluctuations caused by turbidity, $\mathrm{P}^{-\mathrm{PO}_{4}}{ }^{3-}$, and $\mathrm{Cl}^{-}$in $\mathrm{PC} 3$ accounted for $10.4 \%$. It showed that PC3 was affected by salinity, domestic activities, and overflow and erosion [14]. PC4 accounted for $9.5 \%$ of the variation contributed by $\mathrm{N}^{-\mathrm{NO}_{2}}{ }^{-}, \mathrm{N}^{-} \mathrm{NO}_{3}{ }^{-}$,

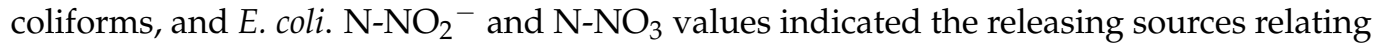
to nitrogen-containing materials and fertilizers while coliform and E. coli originated from animal and fecal materials. PC5 and PC6 explained the water quality variation by $7.7 \%$ and $7 \%$, respectively, with the weak contributions of temperature, ${\mathrm{N}-\mathrm{NH}_{4}}^{+}$, and TN. PC7 showed the contribution of oil and grease at a moderate correlation and TN at a weak correlation. It can be implied that the water quality in the study area was influenced by several different sources such as hydrological conditions, stormwater runoff, and riverbank erosion, domestic activities, urban areas, industrial, and agricultural zones. Among these, urban and agricultural wastes may be the decisive factors in the change of surface water quality in the study area. The water quality indicators should be accounted in the water 
monitoring program, including temperature, $\mathrm{pH}, \mathrm{TSS}, \mathrm{DO}, \mathrm{BOD}, \mathrm{COD},{\mathrm{N}-\mathrm{NH}_{4}}^{+},{\mathrm{N}-\mathrm{NO}_{2}}^{-}$, TN, P-PO ${ }_{4}{ }^{3-}$, coliforms, and E. coli.

\subsection{Clustering Water Quality in the Water Bodies in Dong Thap Province in 2019}

In this study, at a distance Euclid $=5$ (red line), 58 monitoring positions were divided into four clusters (Figure 6). Cluster 1 included only NM43, Cluster 2 included positions NM46, NM28, and NM45; Cluster 3 included locations NM37, NM35, NM77, NM78, NM39, NM57, NM64, NM65, NM69, and NM81; and Cluster 4 comprised the remaining positions. In addition, 12 clusters were divided at Euclid $=3$ (blue line) for a more detailed observation of water quality changes in Dong Thap province. The monitoring clusters were divided into 12 clusters including Cluster 1 (NM43), Cluster 2 (NM46), Cluster 3 (NM28, NM45), Cluster 4 (NM37, NM35, NM77, NM78, NM39, NM57, NM64, NM65), Cluster 5 (NM69, NM81), Cluster 6 (NM26, NM29), Cluster 7 (NM70, NM72, NM61, NM62, NM59, NM42, NM71, NM53, NM60, NM03, NM11), Cluster 8 (NM58), Cluster 9 (NM16, NM66, NM68), Cluster 10 (NM44, NM63), Cluster 11 (NM13, NM67), Cluster 12 (remaining locations). Water quality characteristics in the clusters were assessed by the mean values of the same cluster locations and presented in Table 3.

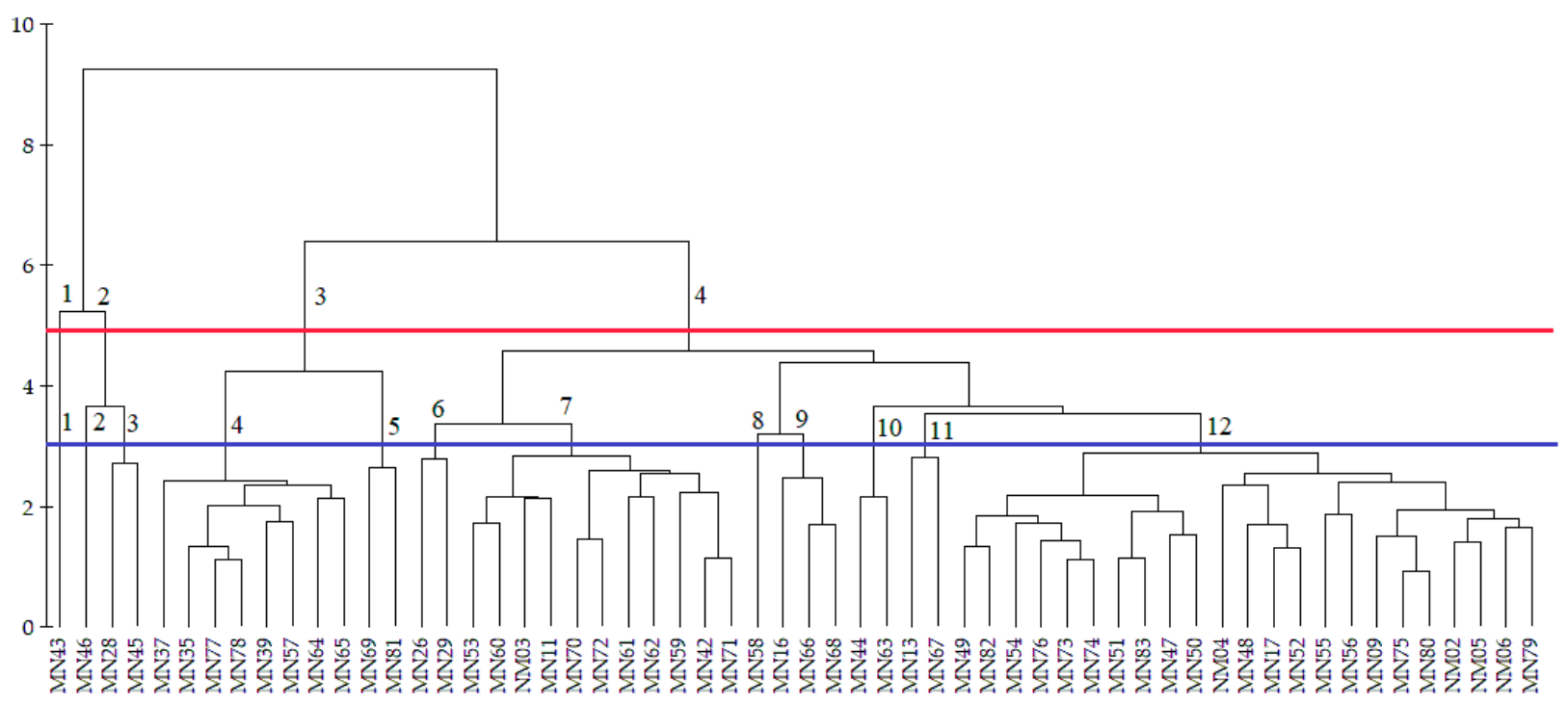

Figure 6. Clustering water quality in the water bodies in Dong Thap province in 2019.

In general, $\mathrm{BOD}, \mathrm{COD}, \mathrm{N}-\mathrm{NH}_{4}{ }^{+}, \mathrm{P}_{-} \mathrm{PO}_{4}{ }^{3-}$, and $\mathrm{E}$. coli in all clusters were higher than the limits of QCVN 08-MT: 2015/BTNMT, column A2. Cluster 1 is located upstream of the Tien River when it flows into Dong Thap province with BOD, COD, N-NH${ }_{4}{ }^{+}, \mathrm{P}_{-} \mathrm{PO}_{4}{ }^{3-}$, and $E$. coli exceeded the standards these parameters had the values lower than those in the remaining groups. Water quality in Cluster 2 was reported to be higher than that in Cluster 1. TSS in cluster 1 far exceeded the limit of QCVN 08-MT: 2015/BTNMT, column A2. Cluster 3 showed a nutrients pollution problem that can be assessed by $\mathrm{N}-\mathrm{NH}_{4}{ }^{+}, \mathrm{N}^{-} \mathrm{NO}_{2}{ }^{-}$, $\mathrm{N}-\mathrm{NO}_{3}{ }^{-}, \mathrm{P}_{-} \mathrm{PO}_{4}{ }^{3-}, \mathrm{TN}$, and TP. In Cluster $3, \mathrm{~N}-\mathrm{NH}_{4}{ }^{+}$and $\mathrm{P}_{-} \mathrm{PO}_{4}{ }^{3-}$ were higher than the permitted value; this could stem from the fact that these locations are in the densely populated area and intersect the tributaries, so they may be affected by integrated pollution sources. Cluster 4 and Cluster 5 had very high concentrations of coliform and E. coli, which were 2.3-4 times higher than the limits of QCVN 08-MT: 2015/BTNMT column A2 for coliform and 26.52-97.42 times for E. coli (Table 3). This showed that these two clusters' pollution characteristic was microbiological pollution, influenced by fecal materials from human and animals. Clusters 4 and 5 were considered the two clusters with the highest pollution level. The water quality of Cluster 6 and Cluster 7 was organic, nutrient, and microbiological pollution indicated by the exceeding limits of the water parameters of BOD, COD, TSS, ${\mathrm{N}-\mathrm{NH}_{4}}^{+},{\mathrm{N}-\mathrm{NO}_{2}}^{-}$, $\mathrm{P}-\mathrm{PO}_{4}{ }^{3-}$, and E. coli. Cluster 8, Cluster 9, Cluster 10, 
and Cluster 11 were polluted because of the water quality parameters of BOD, COD, TSS, $\mathrm{N}-\mathrm{NO}_{2}{ }^{-}, \mathrm{N}-\mathrm{NH}_{4}{ }^{+}, \mathrm{P}-\mathrm{PO}_{4}{ }^{3-}$, coliform, and E. coli all exceeded the limit values of QCVN

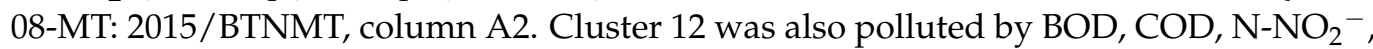
$\mathrm{N}-\mathrm{NH}_{4}{ }^{+}$, coliform, and E. coli. However, the water quality in Cluster 12 had a lower level of microbiological pollution and higher organic matters than those in Cluster 8-Cluster 11 (Table 3).

The above results showed that the water quality in Dong Thap province's water bodies was polluted with suspended solids, nutrients, organic matters, and microorganisms. The primary sources of the water problems could be from hydrological conditions, stormwater runoff, and riverbank erosion, domestic activities, urban areas, and industrial and agricultural zones. The reason is that wastewater and wastes from these sources are characterized by organic matter constituents, which are manifested by large concentrations of COD and BOD and other nutrients such as nitrogen, phosphorus, and microorganisms. Moreover, these sources were also relevant to the local economic development. CA results suggested that the numbers of the monitoring locations on the same rivers/canals in the same cluster can be reduced, so the monitoring points along Tien River, Hau River, and infield canals can be reduced from 58 to 43 positions as indicated in Figure 7. This could save $25.85 \%$ of the monitoring costs. The sites that could be omitted were NM37 or NM38 under Cluster 4 (on Hau river); NM61 or NM72 (Cai Nho river), NM11 or NM53 (Nguyen Van Tiep Canal), NM59 or NM60 or NM03 (Tien river) in Cluster 7; NM13 or NM67 belonging to Cluster 11 (Nguyen Van Tiep Canal); NM49 or NM54 or NM73 or NM50 or NM52 or NM55 or NM05 (Hau river), NM82 or NM83 (So Ha river), NM74 or NM06 (Sa Dec river), NM02 or NM56 (Cao Lanh river) belonging to Cluster 12.

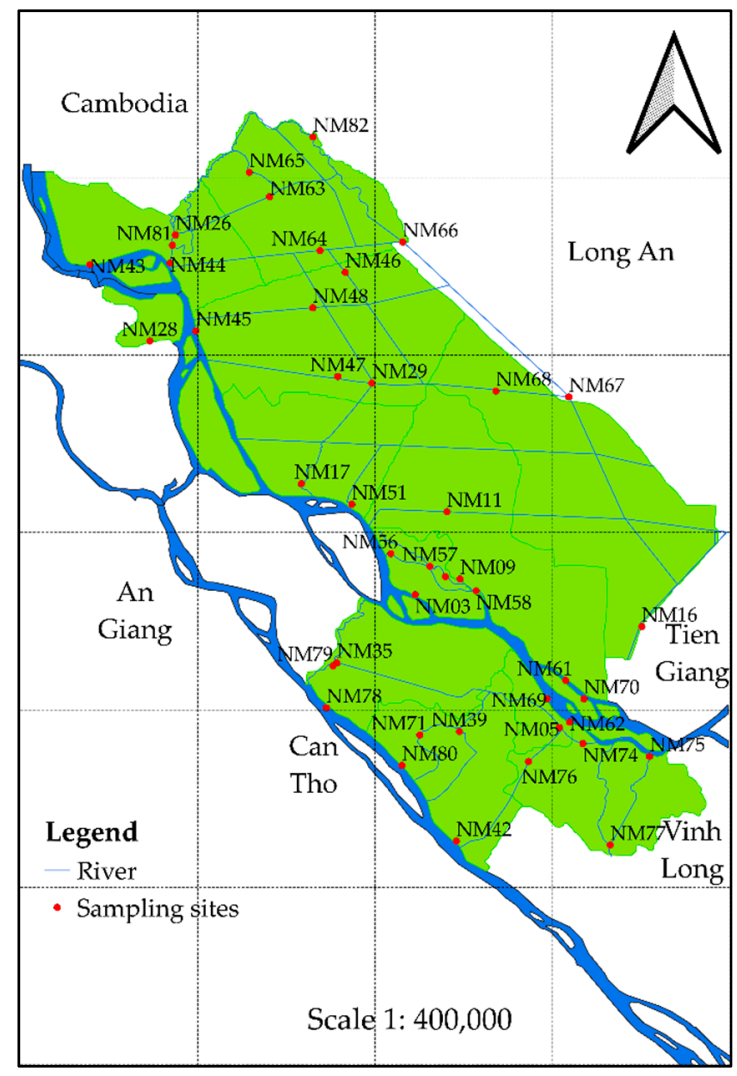

Figure 7. Recommended new sampling sites for water monitoring in Dong Thap province. 
Table 3. Mean values of water parameters in the identified clusters.

\begin{tabular}{|c|c|c|c|c|c|c|c|c|c|c|c|c|c|c|}
\hline Parameters & Units & Clus. 1 & Clus. 2 & Clus. 3 & Clus. 4 & Clus. 5 & Clus. 6 & Clus. 7 & Clus. 8 & Clus. 9 & Clus. 10 & Clus. 11 & Clus. 12 & $\begin{array}{c}\text { QCVN 08-MT:2015/BTNMT } \\
\text { Column A2 }\end{array}$ \\
\hline Temp & ${ }^{\circ} \mathrm{C}$ & 30.35 & 30.45 & 30.64 & 30.5 & 30.64 & 30.79 & 29.97 & 29.93 & 30.43 & 30.2 & 29.88 & 30.31 & - \\
\hline $\mathrm{pH}$ & - & 7.38 & 7.13 & 7.25 & 7.2 & 7.25 & 7.21 & 7.27 & 7.43 & 7.27 & 7.44 & 7.12 & 7.27 & $6-8$ \\
\hline Turb & NTU & 45.98 & 57.28 & 46.29 & 45.32 & 43.84 & 47.1 & 47.37 & 64.18 & 54.64 & 53.33 & 58.84 & 48.36 & - \\
\hline TSS & $\mathrm{mg} \mathrm{L}^{-1}$ & 22.75 & 32 & 30.63 & 43.25 & 52 & 32.13 & 26.34 & 77.5 & 51.08 & 40.25 & 67 & 27.9 & 30 \\
\hline DO & $\mathrm{mg} \mathrm{L}^{-1}$ & 5.45 & 4.83 & 5.12 & 5.05 & 5.15 & 4.88 & 5.17 & 5.17 & 5.21 & 5.17 & 5.39 & 5.13 & 5 \\
\hline BOD & $\mathrm{mg} \mathrm{L}^{-1}$ & 14 & 15.5 & 15.63 & 15.16 & 14.25 & 14.75 & 14.73 & 15.5 & 14.58 & 15.5 & 14.63 & 15.24 & 6 \\
\hline COD & $\mathrm{mg} \mathrm{L}^{-1}$ & 21.25 & 23 & 22.88 & 22.22 & 21.75 & 21.75 & 22.43 & 22.5 & 21.08 & 22.5 & 21.38 & 22.63 & 15 \\
\hline $\mathrm{N}-\mathrm{NH}_{4}+$ & $\mathrm{mg} \mathrm{L}^{-1}$ & 0.36 & 0.41 & 0.39 & 0.38 & 0.41 & 0.42 & 0.36 & 0.37 & 0.35 & 0.41 & 0.39 & 0.39 & 0.3 \\
\hline $\mathrm{N}^{-\mathrm{NO}_{2}}{ }^{-}$ & $\mathrm{mg} \mathrm{L}^{-1}$ & 0.02 & 0.02 & 0.02 & 0.25 & 0.24 & 0.09 & 0.36 & 0.33 & 0.13 & 0.06 & 0.38 & 0.25 & 0.05 \\
\hline $\mathrm{N}^{-N^{-}}{ }_{3}^{-}$ & $\mathrm{mg} \mathrm{L}^{-1}$ & 1.66 & 1.97 & 1.90 & 1.92 & 1.57 & 1.92 & 1.64 & 1.37 & 1.67 & 1.56 & 2.07 & 1.79 & 5 \\
\hline $\mathrm{P}_{-}-\mathrm{PO}_{4}{ }^{3-}$ & $\mathrm{mg} \mathrm{L}^{-1}$ & 0.43 & 0.22 & 0.34 & 0.22 & 0.2 & 0.32 & 0.21 & 0.23 & 0.32 & 0.44 & 0.5 & 0.17 & 0.2 \\
\hline $\mathrm{Cl}^{-}$ & $\mathrm{mg} \mathrm{L}^{-1}$ & 11.84 & 14.54 & 13.9 & 12.18 & 13.97 & 12.48 & 12.08 & 10.92 & 12.22 & 12.48 & 21.34 & 11.98 & 350 \\
\hline $\mathrm{SO}_{4}^{2-}$ & $\mathrm{mg} \mathrm{L}^{-1}$ & 19.78 & 18.33 & 19.16 & 21.37 & 21.56 & 19.43 & 20.71 & 16.9 & 27.3 & 18.95 & 29.3 & 21.39 & - \\
\hline Coliform & MPN $100 \mathrm{~mL}^{-1}$ & 1708 & 2875 & 2475 & 11,553 & 20,600 & 4391 & 3808 & 5100 & 6330 & 7038 & 7866 & 5859 & 5000 \\
\hline E. coli & MPN $10 \mathrm{~mL}^{-1}$ & 420 & 948 & 550 & 1326 & 4871 & 776 & 625 & 1473 & 2049 & 513 & 1410 & 925 & 50 \\
\hline Oil and Grease & $\mathrm{mg} \mathrm{L}^{-1}$ & 0.003 & 0.002 & 0.003 & 0.003 & 0.002 & 0.003 & 0.003 & 0.002 & 0.003 & 0.002 & 0.003 & 0.003 & 0.3 \\
\hline
\end{tabular}




\section{Conclusions}

The quality of surface water in Dong Thap in 2019 has been polluted, as manifested by TSS, BOD, COD, N-NH ${ }_{4}{ }^{+}, \mathrm{N}-\mathrm{NO}_{2}{ }^{-}, \mathrm{P}_{-} \mathrm{PO}_{4}{ }^{3-}$, coliform, and E. coli exceeding the limits of QCVN 08-MT: 2015/BTNMT, column A2. ANOVA analysis showed that water quality has seasonally changed significantly through surveys (except DO and oil and grease). The WQI index showed that the overall water quality in the south of Dong Thap has lower water quality than in the north of Dong Thap, and the water quality ranged from poor to medium. PCA and Pearson analysis showed 12 water monitoring indicators including temperature, $\mathrm{pH}$, TSS, $\mathrm{DO}, \mathrm{BOD}, \mathrm{COD}, \mathrm{N}-\mathrm{NH}_{4}{ }^{+}, \mathrm{N}-\mathrm{NO}_{2}{ }^{-} \mathrm{TN}, \mathrm{P}-\mathrm{PO}_{4}{ }^{3-}$, coliforms, and E. coli significantly contributing to affecting surface water quality in Dong Thap province. These indicators were correlated only at the average-weak level since several external factors possibly influenced this open water system. Cluster analysis results showed that the water quality assessment could only need 43 locations, reducing 15 positions compared to the original, and saving about $25.85 \%$ of the monitoring cost. The quality of surface water in Dong Thap province is influenced by many different sources such as hydrological conditions, stormwater runoff, riverbank erosion, domestic activities, urban, industrial, and agricultural zones. Further research should examine the contribution of these pollution sources to an effective management strategy. The present study results can provide critical information for water managers in Dong Thap and the Mekong delta provinces.

Supplementary Materials: The following are available online at https:/ / www.mdpi.com/2073-444 1/13/3/336/s1, Table S1: Description of the monitoring locations.

Author Contributions: Conceptualization, N.T.G. and H.T.H.N.; methodology, N.T.G.; software, H.T.H.N.; validation, N.T.G., H.T.H.N., and P.K.A.; formal analysis, H.T.H.N.; investigation, P.K.A.; resources, N.T.G.; data curation, N.T.G.; writing—original draft preparation, H.T.H.N. and P.K.A.; writing - review and editing, N.T.G.; visualization, H.T.H.N.; supervision, N.T.G.; project administration, N.T.G.; All authors have read and agreed to the published version of the manuscript.

Funding: This research received no external funding.

Institutional Review Board Statement: The study did not require ethical approval, because it did not involve humans or animals.

Informed Consent Statement: Informed consent was obtained from all subjects involved in the study.

Data Availability Statement: Not applicable.

Acknowledgments: The authors would like to thank the Department of Natural Resources and Environment of Dong Thap province for providing the monitoring data. All analysis and evaluation in this study are the authors' scientific perspectives, not necessarily representing the agency's views providing the data.

Conflicts of Interest: The authors declare no conflict of interest.

\section{References}

1. Xo, L.Q. Publicizing the Master Plan for Irrigation in the Mekong River Delta in Terms of Climate Change and Sea Level Rise in 2012. Available online: https:/ / siwrp.org.vn/tin-tuc/cong-bo-quy-hoach-tong-the-thuy-loi-dong-bang-song-cuu-long-trongdieu-kien-bien-doi-khi-hau-nuoc-bien-dang_149.html (accessed on 28 January 2020).

2. Ogston, A.S.; Alison, M.A.; Mullarney, J.C. Nittouer Sediment and hydro-dynamics of the Mekong Delta: From tidal river to continental shelf. Cont. Shelf Res. 2017, 147, 1-6. [CrossRef]

3. Brunier, G.; Edward, J.A.; Marc, G.; Mireille, P.; Philippe, D. Recent morphological changes in the Mekong and Bassac river channels, Mekong delta: The marked impact of river-bed mining and implications for delta destabilisation. Geomorphology 2014, 224, 177-191. [CrossRef]

4. Dang, T.D.; Cochrane, T.A.; Arias, M.E.; Tri, V.P.D. Future hydrological alterations in the Mekong Delta under the impact of water resources development, land subsidence and sea level rise. J. Hydrol. Reg. Stud. 2015, 15, 119-133. [CrossRef]

5. Manh, N.V.; Dung, N.V.; Hung, N.N.; Kummu, M.; Merz, B.; Apel, H. Future sediment dynamics in the Mekong Delta floodplains: Impacts of hydropower development, climate change and sea level rise. Glob Planet Chang. 2015, 127, 22-33. [CrossRef]

6. Kakonen, M. Mekong Delta at the crossroads: More control or adaptation. Swed. Acad. Sci. 2008, 37, $205-217$. 
7. Turner, S.; Pangarre, G.; Mather, R.J. Water governace: A situational analysis of Cambodia, Lao PDR and Vietnam. In Mekong Region Water Dialogues; IUCC: Gland, Switzerland, 2009; Volume 2, p. 59.

8. Truong, T.V. River basin management challenges and solutions. Available online: http://www.vncold.vn/Web/Content.aspx? distid=3798 (accessed on 28 January 2020).

9. Vietnam Environmental Protection Agency. National Technical Regulation on Surface Water Quality (QCVN 08-2015/BTNMT); Vietnam Environmental Protection Agency: Hanoi, Vietnam, 2015.

10. Zhou, F.; Liu, Y.; Guo, H. Application of multivariate statistical methods to water quality assessment of the water courses in north western new territories Hong Kong. Environ. Monit. Assess. 2007, 132, 1-13. [CrossRef]

11. Feher, I.C.; Zaharie, M.; Oprean, I. Spatial and seasonal variation of organic pollutants in surface water using multivariate statistical techniques. Water Sci. Technol. 2016, 74, 1726-1735. [CrossRef]

12. Barakat, A.; Mohamed, E.B.; Jamila, R.; Brahim, A.; Mohamed, S. Assessment of spatial and seasonal water quality variation of Oum Er Rbia River (Morocco) using multivariate statistical techniques. Int. Soil Water Conserv. Res. 2016, 4, 284-292. [CrossRef]

13. Zeinalzadeh, K.; Rezaei, E. Determining spatial and temporal changes of surface water quality using principal component analysis. J. Hydrol. Reg. Stud. 2017, 13, 1-10. [CrossRef]

14. Howladar, M.F.; Numanbakth, M.A.A.; Faruque, M.O. An application of water quality index (WQI) and multivariate statistics to evaluate water quality around maddhapara granite mining industrial area, dinajpur, Bangladesh. Environ. Syst. Res. 2017, 6, 1-18. [CrossRef]

15. Minh, H.V.T.; Kurasaki, M.; Ty, T.V.; Tran, D.Q.; Le, K.N.; Avtar, R.; Rahman, M.; Osaki, M. Effects of Multi-Dike Protection Systems on Surface Water Quality in the Vietnamese Mekong Delta. Water 2019, 11, 1010. [CrossRef]

16. APHA; AWWA. WEF Standard Methods of for the Examnination of Water and Wastewwater, 23rd ed.; American Public Health Association: Washington, DC, USA, 2017.

17. Vietnam Environment Administration. Decision 1460/QD-TCMT Dated November 12, 2019 on the Issuing of Technical Guide to Calculation and Disclosure Vietnam Water Quality Index (VN_WQI); Vietnam Environment Administration: Hanoi, Vietnam, 2019.

18. Heale, R.; Twycross, A. Validity and reliability in quantitative studies. Evid. Based Nurs. 2015, 18, 66-67. [CrossRef] [PubMed]

19. Prathumratana, L.; Sthiannopkao, S.; Kim, K.W. The relationship of climatic and hydrological parameters to surface water quality in the lower Mekong River. Environ. Int. 2008, 34, 860-866. [CrossRef] [PubMed]

20. Lien, N.T.K.; Huy, L.Q.; Oanh, D.T.H.; Phu, T.Q.; Ut, V.N. Water quality in mainstream and tributaries of Hau River. Can Tho Univ. J. Sci. 2016, 43, 68-79.

21. Ly, N.H.T.; Giao, N.T. Surface water quality in canals in An Giang province, Viet Nam, from 2009 to 2016. J. Vietnam. Environ. 2018, 10, 113-119. [CrossRef]

22. Giao, N.T. Surface water quality at the branches adjacent to Hau river in Can Tho city. Sci. Technol. J. Agric. Rural Dev. 2020, 15, 79-86.

23. Panigrahi, S.; Acharya, B.C.; Panigrahy, R.C.; Nayak, B.K.; Banarjee, K.; Sarkar, S.K. Anthropogenic Impact on Water Quality of Chilika Lagoon RAMSAR Site: A Statistical Approach. Wetl. Ecol. Manag. 2007, 15, 113-126. [CrossRef]

24. Kankal, N.C.; Indurkar, M.M.; Gudadhe, S.K.; Wate, S.R. Water Quality Index of Surface Water Bodies of Gujarat, India. Asian J. Exp. Sci. 2012, 26, 39-48.

25. Rakotondrabe, F.; Ngoupayou, J.R.N.; Mfonka, Z.; Rasolomanana, E.H.; Abolo, A.J.N.; Ako, A.A. Water quality assessment in the Bétaré-Oya gold mining area (East-Cameroon): Multivariate statistical analysis approach. Sci. Total Environ. 2018, 610, 831-844. [CrossRef]

26. Giau, V.T.N.; Tuyen, P.T.B.; Trung, N.H. Assessing surface water quality of Can Tho river in the period of 2010-2014 using water quality indicator (WQI). Can Tho Univ. J. Sci. 2019, 55, 105-113.

27. Olajire, A.A.; Imeppeoria, F.E. Water quality assessment of Osun River: Studies on inorganic nutrients. Environ. Monit. Assess. 2001, 69, 17-28. [CrossRef] [PubMed]

28. Ty, D.V. Evaluation of water quality in Binh Thien lagoon, An Giang province. Can Tho J. Sci. 2018, 54, $125-131$.

29. Palma, P.; Fialho, S.; Lima, A.; Mourinha, C.; Penha, A.; Novais, M.H.; Rosado, A.; Morais, M.; Potes, M.; Costa, M.J.; et al. Land-Cover Patterns and Hydrogeomorphology of Tributaries: Are These Important Stressors for the Water Quality of Reservoirs in the Mediterranean Region? Water 2020, 12, 2665. [CrossRef]

30. Ongley, E.D. Water Quality of the Lower Mekong River. In The Mekong; Academic press: Montreal, QC, Canada, 2009; pp. 297-320.

31. Kutoka, G. Management of Eutrophication in Small Dams with Both Urban and Rural Catchments in Zimbabwe: A Case Study of Rufaro Dam, Marondera, Zimbabwe. A thesis submitted in partial fulfillment of the requirements for the degree of Master of Science in Tropical Resources Ecology. Master's Thesis, University of Zimbabwe, Harare, Zimbabwe, 2012.

32. Truc, D.T.; Phat, P.H.; Giang, N.D.; Toan, P.V.; Tri, V.P.D. The water surface quality of Tien river in the area of Tan Chau district, An Giang province. Can Tho J. Sci. 2019, 55, 53-60.

33. Sharma, R.C. Effective Mitigation: The Cumulative Impact of Climate Change on Transportation Network and Its Implications on Aquatic Biodiversity of Ganges Headwaters, Garhwal Himalayas. In Proceedings of the 2009 International Conference on Ecology and Transportation (ICOET 2009), Duluth, MN, USA, 13-17 September 2009; pp. 512-522.

34. Servais, P.; Garcia-Armisen, T.; George, I.; Billen, G. Fecal bacteria in the riversof the Seine drainage network (France): Sources, fate and modeling. Sci. Total Environ. 2007, 375, 152-167. [CrossRef] [PubMed] 
35. Ouattara, N.; Passerat, J.; Servais, P. Faecal contamination of water and sedimentin the rivers of the Scheldt drainage network. Environ. Monit. Assess. 2011, 183, 243-257. [CrossRef]

36. Li, J.X.; Liao, W.G. An analysis on the possibilities of eutrophication in the Three Gorges Reservoir. Sci. Technol. Rev. 2003, 9, $49-52$.

37. Wondie, T.A. The Impact of Urban Storm Water Runoff and Domestic Waste Effluent on Water Quality of Lake Tana and local Groundwater Near the City of Bahir Dar, Ethiopia. Ph.D. Dissertation, Cornell University Ithaca, New York, NY, USA, 2009.

38. Geurts, J.J.M.; Sarneel, J.M.; Willers, B.J.C.; Roelofs, J.G.M.; Verhoeven, J.T.A.; Lamers, L.P.M. Interacting effects of sulphate pollution, sulphide toxicity and eutrophication on vegetation development in fens: A mesocosm experiment. Environ. Pollut. 2009, 157, 2072-2081. [CrossRef]

39. Fox, G.A.; Purvis, R.A.; Penn, C.J. Streambanks: A net source of sediment and phosphorus to streams and rivers. J. Environ. Manag. 2016, 181, 602-614.

40. Han, Y.; Lau, S.L.; Kayhanian, M.; Stenstrom, M.K. Characteristics of highway stormwater runoff. Water Environ. Res. 2006, 78, 2377-2388.

41. Ruiz, G.; Jeison, D.; Rubilar, O.; Ciudad, G.; Chamy, R. Nitrification-denitrification via nitrite accumulation for nitrogen removal from wastewaters. Bioresour. Technol. 2006, 97, 300-335. [CrossRef] [PubMed]

42. Varol, M. Use of water quality index and multivariate statistical methods for the evaluation of water quality of a stream affected by multiple stressors: A case study. Environ. Pollut. 2020, 266, 115417. [CrossRef] [PubMed]

43. Xue, F.; Tang, J.; Dong, Z.; Liu, H.; Zhang, X.; Holden, N.M. Tempo-spatial controls of total coliform and E. coli contamination in a subtropical hilly agricultural catchment. Agric. Water Manag. 2018, 200, 10-18. [CrossRef]

44. Minh, H.V.T.; Avtar, R.; Kumar, P.; Le, K.N.; Kurasaki, M.; Ty, T.V. Impact of Rice Intensification and Urbanization on Surface Water Quality in An Giang Using a Statistical Approach. Water 2020, 12, 1710.

45. Kale, A.; Bandela, N.; Kulkarni, J.; Raut, K. Factor analysis and spatial distribution of water quality parameters of Aurangabad District, India. Groundw. Sustain. Dev. 2020, 10, 100345. [CrossRef]

46. Boyacioglu, H.; Boyacioglu, H. Water pollution sources assessment by multivariate statistical methods in the Tahtali Basin, Turkey. Environ. Geol. 2008, 54, 275-282.

47. Rodrigues, M.; Cravo, A.; Freire, P.; Rosa, A.; Santos, D. Temporal assessment of the water quality along an urban estuary (Tagus estuary, Portugal). Mar. Chem. 2020, 223, 103824. [CrossRef] 